Article

\title{
Evaluation of the Characteristics of Native Wild Himalayan Fig (Ficus palmata Forsk.) from Pakistan as a Potential Species for Sustainable Fruit Production
}

\author{
Muhammad Riaz Khan ${ }^{1,2}$, Muhammad Azam Khan ${ }^{1, *} \mathbb{0}$, Umer Habib ${ }^{1}$, Mehdi Maqbool ${ }^{2, * \mathbb{C}}$, \\ Rashid Mehmood Rana ${ }^{3}$ (D), Shahid Iqbal Awan ${ }^{4,5}$ and Boris Duralija ${ }^{6}$ (D) \\ 1 Department of Horticulture, Faculty of Crop and Food Sciences, PMAS-Arid Agriculture University, \\ Rawalpindi 46300, Pakistan; mriazkhan@upr.edu.pk (M.R.K.); umer@uaar.edu.pk (U.H.) \\ 2 Department of Horticulture, Faculty of Agriculture, University of Poonch Rawalakot, \\ Rawalakot 12350, Pakistan \\ 3 Department of Plant Breeding and Genetics, Faculty of Crop and Food Sciences, PMAS-Arid \\ Agriculture University, Rawalpindi 46300, Pakistan; rashid.pbg@uaar.edu.pk \\ 4 Department of Plant Breeding and Molecular Genetics, Faculty of Agriculture, University of Poonch \\ Rawalakot, Rawalakot 12350, Pakistan; sia23@cornell.edu \\ 5 Plant Pathology and Plant-Microbe Biology, School of Integrative Plant Science, Cornell University, Cornell \\ AgriTech, Geneva, NY 14456, USA \\ 6 Department of Pomology, Division of Horticulture and Landscape Architecture, Faculty of Agriculture, \\ University of Zagreb, 10000 Zagreb, Croatia; bduralija@agr.hr \\ * Correspondence: drazam1980@uaar.edu.pk (M.A.K.); mehdimaqbool@upr.edu.pk (M.M.)
}

check for

updates

Citation: Khan, M.R.; Khan, M.A.; Habib, U.; Maqbool, M.; Rana, R.M.; Awan, S.I.; Duralija, B. Evaluation of the Characteristics of Native Wild Himalayan Fig (Ficus palmata Forsk.) from Pakistan as a Potential Species for Sustainable Fruit Production. Sustainability 2022, 14, 468. https:/ / doi.org/10.3390/su14010468

Academic Editor: Francesco Sottile

Received: 11 December 2021

Accepted: 29 December 2021

Published: 2 January 2022

Publisher's Note: MDPI stays neutral with regard to jurisdictional claims in published maps and institutional affiliations.

Copyright: (C) 2022 by the authors. Licensee MDPI, Basel, Switzerland. This article is an open access article distributed under the terms and conditions of the Creative Commons Attribution (CC BY) license (https:// creativecommons.org/licenses/by/ $4.0 /)$.
Abstract: Wild Himalayan figs (Ficus palmata Forsk.), native to East Asia and the Himalayan region, are closely related to the well-known cultivated fig (Ficus carica L.), which is grown mainly in the Mediterranean region. The Pakistani state of Azad Jammu and Kashmir has a rich variety of figs. However, no comprehensive study has been carried out to utilise the diversity of these wild figs for possible use in sustainable fruit production. Therefore, the present study was designed to assess the variability of 35 wild fig accessions using quantitative and qualitative traits. Descriptive statistics were used to measure quantitative characteristics, while the coefficient of variance (CV \%) was analysed using $\mathrm{SAS}^{\circledR}$ version 9.1. A principal component analysis (PCA) and multivariate analysis were performed using R Studio (v1.1.4). Pearson correlation coefficients between characteristics were obtained using SPSS software. The studied accessions showed high variability and the coefficient of variation (CV) ranged from 4.46-14.81\%. Days to maturity varied from 71 to 86 , leaf area from 38.55 to $90.06 \mathrm{~cm}^{2}$. The fruit length, fruit diameter and fruit weight ranged from 11.25 to $29.85 \mathrm{~mm}$, 11.85 to $27.49 \mathrm{~mm}$ and 2.65 to $9.66 \mathrm{~g}$, respectively. The photosynthetic activity and total chlorophyll content also varied from 7.94 to $10.22 \mu \mathrm{mol} \mathrm{CO} \mathrm{Cm}^{-2} \mathrm{~s}^{-1}$ and 37.11 to $46.48 \mu \mathrm{gml}^{-1}$. In most of the fig accessions studied, apical dominance was found to be 'absent' while fruit shape was observed to be 'globular'. A strong correlation was observed between all the studied characteristics. In the PCA analysis, all 35 fig accessions were distributed in four quadrants and showed a great diversity. This could be a valuable gene pool for future breeding studies and provide improved quality varieties. Wild Himalayan figs from the wild are well adapted to local pedoclimatic conditions and, combined with easy propagation and production can contribute to the local economy and have a significant impact on the socio-economic and ecological balance. The results of this study show high variability in some of the studied traits of 35 accessions from different parts of Northeast Pakistan, indicating their good potential for further enhancement and utilisation in sustainable agricultural production.

Keywords: native germplasm; temperate fruit; wild fig; biodiversity; conservation

\section{Introduction}

Figs are one of the oldest domesticated fruits of the Mediterranean region [1] and are native to western Asia and eastern parts of the Mediterranean countries [2]. They were 
domesticated five thousand years earlier than millet and wheat [3]. Based on historical facts, scientists are very interested in exploring the genetic diversity of these species [4]. Figs are gynodioecious species and are pollinated by the wasp (Blastophaga psenes L.) [4,5]. The edible part of figs is the fruit, which is fleshy, hollow and receptive [6]. There are three types of figs, depending on how they are grown, e.g., the Common type, the Smyrna type and the San Pedro type. The Common type produces parthenocarpic fruit without pollination for either the breba (first) or the main crop. The Smyrna type, on the other hand, requires caprifig for pollination, while the San Pedro type produces the first fruit without pollination while the second fruit requires caprifig for pollination [7]. Fig types have generally adapted to different soils and climatic conditions and are therefore widely grown in many regions of the world.

Fig fruits are a good source of minerals and bioactive compounds. They are considered healthy fruits because they are a rich source of minerals (iron, calcium, potassium), amino acids (aspartic acid, glutamine) fiber and carotenoids such as lycopene, cryptoxanthin and $\beta$-carotene $[6,8]$. Fresh figs provide a large amount of antioxidants, polyphenols and flavonoids (catechin, epicatechin) [9]. In addition, figs are free of fats and cholesterol and are a good source of sugars (fructose, glucose), organic acids and volatile compounds that enhance the flavour of the fruit [8,9]. In addition, fig fruits are a rich source of phenolic compounds that effectively contribute to colour formation, flavour and aroma $[10,11]$. Moreover, the colour of the flesh and skin affect the accumulation of phenolic compounds and the antioxidant capacity in fruits [12]. Recently, several studies have shown that fig cultivars and growing locations influence antioxidant potential and other chemical properties such as total soluble solids, sugars, and organic acids [8,12]. It has also been reported that fig fruits, roots and leaves are used in various conventional medicines that are effective against certain ailments such as gastrointestinal, respiratory, cardiovascular and anti-inflammatory problems [13].

The genetic diversity of fruit plant species is under threat by commercialization, which must be preserved using existing genetic resources. This will not only ensure the survival of such species for long term studies but also ensure sufficient variability among species for future breeding programs. It is well known that wild species such as Ficus palmata in northeastern Pakistan are well adapted to local pedoclimatic conditions and, combined with easy propagation and production can contribute to the local economy and have a significant impact on socioeconomic and ecological balance. Farmers have good opportunities in this region to use wild figs to increase and secure their income and provide a sustainable food source by using indigenous wild fruit species $[14,15]$.

The unripe fruits and young shoots are cooked and eaten as a vegetables [16]. The leaves of some forage plants are fed to animals in the acute winter season, and F. palmata is one of the most important winter forage trees in some areas [17]. Energy plantations have proven to be a viable agroforestry system for the hills and F. palmata has proved to be suitable for energy plantations [18]. F. palmata biomass is an excellent source of milkcoagulating enzymes [19]. Some studies provide a pharmacological basis for the traditional use of the fruits of $F$. palmata in the treatment of pain and indicate the future prospects of the wild fig in the medicinal industry [20].

In Azad Jammu and Kashmir, most of the edible fruit species are not properly conserved. However, a few species of figs are cultivated by the local population, which reduces the threat to the rare wild edible fruit trees found in the region. The state of Azad Jammu and Kashmir is part of the Lesser Himalayan mountain ranges in north-eastern Pakistan, extending from the low subtropical plains in the south to high alpine slopes with altitudes of $3000 \mathrm{~m}$ or more in the north [21]. Topographic variations, altitudinal aspects and vegetation cover have a great influence on the climatic conditions of the mountain ranges of the Lesser Himalaya. Therefore, the inner and outer parts of the ranges differ greatly in terms of rainfall, snowfall and temperature, which in turn affect the production of wild edible fruits [22]. In Azad Jammu and Kashmir, edible figs are generally grown in natural forests and marginal lands, with very low economic returns as most of the fruit is consumed 
locally. The total area under fig cultivation is 125 hectares and the production is 500 tonnes in Pakistan, which is very low compared to the rest of the world [22].

Since figs are perishable, they are dried naturally under sunlight in Kashmir [23]. Figs produced in central Kashmir have a very high fiber content. They are also reported to be a very good source of calcium and potassium [23]. Dried Kashmiri figs contain omega-3 and omega- 6 fatty acids, which are considered useful for preventing heart disease and can cure sore throats due to their high mucilage content [23]. Due to their delicious taste and freshness, the dried figs enjoy high demand from customers within and outside Kashmir. In Azad Jammu and Kashmir, Pakistani fig species, particularly F. palmata, have a large number of accessions, which are under threat of genetic erosion. Furthermore, no comprehensive study has been conducted to exploit the diversity of these wild figs for possible use in sustainable fruit production. Therefore, the present study was undertaken as an initiative measure to assess the morphological and pomological diversity of the existing germplasm of wild edible fig in Azad Jammu and Kashmir and to identify promising trees with high fruit quality.

\section{Materials and Methods}

Thirty-five wild figs (Ficus palmate Forsk.) were collected from 10 districts [Mirpur (MP), Bhimber (BH), Kotli (KT), Sudhnuti (SD), Poonch (PN), Bagh (BG), Haveli (HV), Muzaffarabad (MZ), Jhelum Valley (JV), Neelum (NL)] representing three divisions, i.e., Mirpur, Poonch and Muzaffarabad of Azad Jammu and Kashmir, Pakistan (Table 1, Figure 1).

For data analysis, 10 mature leaves and 10 mature fruits were taken randomly from each tree and 10 trees were used per replicate. A total of 33 traits (13 qualitative and 20 quantitative) were examined. A digital caliper (model: 0-150 mm; MC China) with an accuracy of $0.10 \mathrm{~mm}$ was used to measure petiole length, petiole thickness, fruit length, fruit diameter, fruit petiole length, petiole width, and fruit skin thickness. The weight of the fruit was determined with the help of an electric balance. Penetrometer (Willowbank Electronics, Waiohiki, New Zealand) was used to determine fruit firmness, while fruit colour was measured using chromameter (model: CR-400, Konica Minolta, Inc., Tokyo, Japan). Portable photosynthetic apparatus CIRAS-3 (PP Systems, Amesbury, MA, USA) was used to measure photosynthetic activity while total chlorophyll content was measured by Arnon's method [24] using spectrophotometer (Model: SP -3000 Plus Optima, Tokyo, Japan) in postharvest laboratory of Department of Horticulture, PMAS Arid Agriculture, Rawalpindi, Pakistan.

\subsection{Evaluation of the Qualitative Characteristics}

Thirteen qualitative characteristics, i.e., tree growth habit (TGH), tree vigour (TVg), relative degree of branching (RDB), apical dominance (ADm), leaf colour $(\mathrm{LCl})$, leaf shape (LSh), leaf base shape (LBS), leaf margin (LMr), leaf margin serration (LMrS), leaf veining $(\mathrm{LVn})$, fruit shape $(\mathrm{FSh})$, flesh colour $(\mathrm{ClF})$ and peelability $(\mathrm{Pe})$ were visually recorded to assess diversity using fig descriptors provided by IPGRI and CIHEAM [25].

\subsection{Assessment of Quantitative Traits}

Twenty quantitative traits, i.e., days to maturity (DtM), shoot length (SLn), number of leaves per shoot (nLS), leaf length (LLn), leaf width $(\mathrm{LWd})$, leaf area (LAr), leaf petiole length (LPLn), leaf petiole thickness (LPTh), number of fruits per shoot (nFS), fruit length (Fln), fruit diameter (FDm), fruit stalk length (FSLn), fruit weight (FWt), ostiole width (OWd), fruit skin thickness (FSTh), fruit firmness (FFn), colour $\mathrm{L}^{*}\left[\left(\mathrm{ClL}^{*}\right)\right.$, white (100) to black $(0)]$, colour a* $\left[\left(\mathrm{Cla}^{*}\right)\right.$, green $(-)$ to red $\left.(+)\right]$, photosynthetic activity $(\mathrm{PAc})$ and total chlorophyll content (TCC) were observed to analyse diversity among 35 wild fig accessions. DtM means maturity of fruits of the current year calculated from the time of fruit set to the time of fruit maturity. 


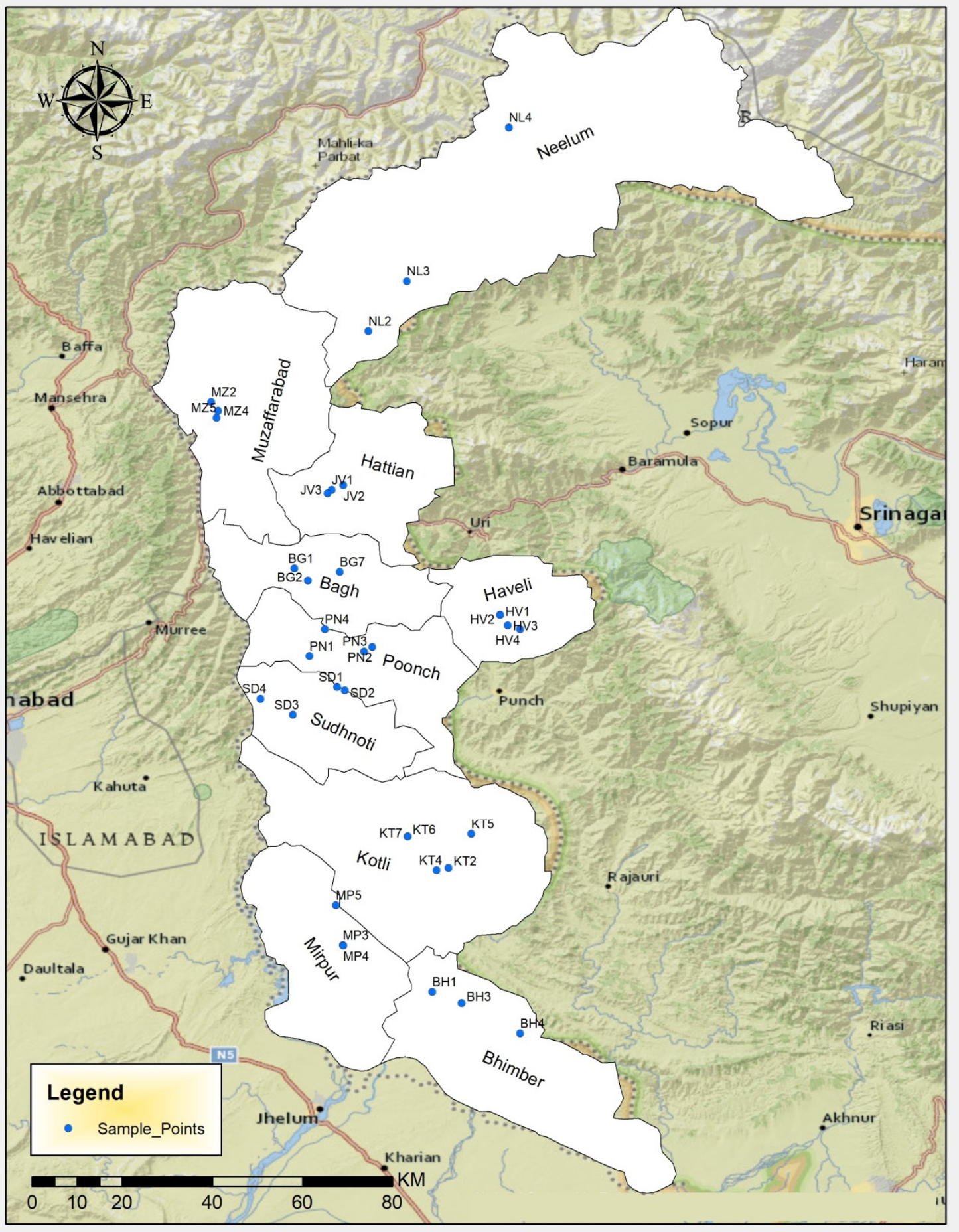

Figure 1. Collection sites of fig accessions in Azad Jammu \& Kashmir, Pakistan.

\subsection{Statistical Analysis}

For the statistical data analysis, average values obtained from 35 wild fig accessions regarding phenotypic measurements linked to 33 characteristics were used. Means, minimum values, maximum values, standard deviation (SD) and coefficient of variance (CV\%) were analysed for all the parameters using $S A S^{\circledR}$ version 9.1, while the frequency distribution of qualitative characteristics was analysed using Microsoft Excel 2016. Principal component analysis (PCA) and multivariate analysis were performed using R Studio (v1.1.4) statistics 
software. Pearson's correlation coefficients between the characters were determined using SPSS software.

Table 1. Detail of 35 wild fig (Ficus palmata) accessions from Azad Jammu and Kashmir, Pakistan.

\begin{tabular}{|c|c|c|c|c|}
\hline Accession ID & Collection Site & Latitude (N) & Longitude (E) & Elevation (m.a.s.l) \\
\hline MP3 & Chakshawari & $33^{\circ} 15.685$ & $73^{\circ} 46.813$ & 438 \\
\hline MP4 & Chakshawari & $33^{\circ} 15.651$ & $73^{\circ} 46.880$ & 373 \\
\hline MP5 & Dadyal & $33^{\circ} 20.689$ & $73^{\circ} 46.739$ & 413 \\
\hline BH1 & Dabal Poona & $33^{\circ} 10.074$ & $73^{\circ} 57.524$ & 506 \\
\hline BH3 & Chadroon & $33^{\circ} 08.739$ & $74^{\circ} 01.013$ & 582 \\
\hline $\mathrm{BH} 4$ & Samahni & $33^{\circ} 05.139$ & $74^{\circ} 08.067$ & 595 \\
\hline KT2 & Tanyote & $33^{\circ} 24.933$ & $73^{\circ} 59.468$ & 621 \\
\hline KT4 & Dhongi & $33^{\circ} 24.623$ & $73^{\circ} 58.027$ & 766 \\
\hline KT5 & Supply Nakyal & $33^{\circ} 28.968$ & $74^{\circ} 02.202$ & 595 \\
\hline KT6 & Kotli City & $33^{\circ} 28.656$ & $73^{\circ} 54.557$ & 642 \\
\hline KT7 & Kotli City & $33^{\circ} 28.656$ & $73^{\circ} 54.565$ & 629 \\
\hline SD1 & Kotara & $33^{\circ} 47.118$ & $73^{\circ} 46.635$ & 1843 \\
\hline SD2 & Kotara & $33^{\circ} 46.219$ & $73^{\circ} 47.045$ & 1726 \\
\hline SD3 & Palandri & $33^{\circ} 43.334$ & $73^{\circ} 40.836$ & 1361 \\
\hline SD4 & Sawa Cross & $33^{\circ} 45.244$ & $73^{\circ} 36.919$ & 742 \\
\hline PN1 & Kot Maty Khan & $33^{\circ} 50.339$ & $73^{\circ} 42.809$ & 1989 \\
\hline PN2 & Namnota & $33^{\circ} 51.479$ & $73^{\circ} 50.311$ & 1937 \\
\hline PN3 & Khaigala & $33^{\circ} 50.925$ & $73^{\circ} 49.341$ & 1733 \\
\hline PN4 & Lowar Parat & $33^{\circ} 53.563$ & $73^{\circ} 44.648$ & 1121 \\
\hline BG1 & Mallot & $34^{\circ} 00.872$ & $73^{\circ} 41.011$ & 1734 \\
\hline BG2 & Jaglari & $33^{\circ} 59.402$ & $73^{\circ} 42.637$ & 1561 \\
\hline BG7 & Paddar & $34^{\circ} 00.459$ & $73^{\circ} 46.456$ & 1232 \\
\hline HV1 & Halan North & $33^{\circ} 55.278$ & $74^{\circ} 05.663$ & 1743 \\
\hline HV2 & Halan North & $33^{\circ} 55.271$ & $74^{\circ} 05.669$ & 1742 \\
\hline HV3 & Halan South & $33^{\circ} 54.026$ & $74^{\circ} 06.574$ & 1555 \\
\hline HV4 & Kahuta City & $34^{\circ} 53.703$ & $74^{\circ} 06.708$ & 1408 \\
\hline MZ2 & Mang Umer Khan & $34^{\circ} 20.795$ & $73^{\circ} 31.024$ & 950 \\
\hline MZ4 & Langarpura & $34^{\circ} 19.771$ & $73^{\circ} 31.843$ & 876 \\
\hline MZ5 & Subri & $34^{\circ} 18.904$ & $73^{\circ} 31.657$ & 850 \\
\hline JV1 & Jigal & $34^{\circ} 10.292$ & $73^{\circ} 45.460$ & 972 \\
\hline JV2 & Goharabad & $34^{\circ} 10.841$ & $73^{\circ} 46.863$ & 1089 \\
\hline JV3 & Dhani Shadra & $34^{\circ} 09.862$ & $73^{\circ} 44.972$ & 1125 \\
\hline NL2 & Barrian & $34^{\circ} 26.358$ & $73^{\circ} 48.574$ & 1147 \\
\hline NL3 & Jura & $34^{\circ} 29.303$ & $73^{\circ} 49.863$ & 1239 \\
\hline NL4 & Athmuqam & $34^{\circ} 35.287$ & $73^{\circ} 54.483$ & 1460 \\
\hline
\end{tabular}

m.a.s.l: Meter above sea level.

\section{Results}

\subsection{Descriptive Results for Qualitative Characteristics}

The results of the qualitative traits including tree, leaf and fruit characteristics are summarised in Table 2. A high variability was observed in all the traits studied except for ease of peeling. Of the two growth forms observed, 'semi-erect' growth form was the predominant $(77.14 \%$ ) while $22.86 \%$ of the fig accessions (BH3, SD2, PN2, BG2, MZ2, NL2) had 'spreading' growth form. Most of the fig accessions (74.29\%) had 'high' vigour while the remaining 25.71\% (MP3, BH4, KT2, KT4, SD4, PN2, BG2, MZ2, NL4) had 'intermediate' tree vigour. Regarding the relative degree of branching, $77.15 \%$ of the fig accessions had 'dense' branching, while 22.85\% of the fig accessions (MP5, BH4, KT2, PN4, BG7, HV4, MZ5, NL4) had 'intermediate' branching type. No apical dominance was observed in $74.28 \%$ of the fig accessions, while apical dominance was present in $25.72 \%$ of the fig accessions (BH1, BH4, KT7, SD3, PN4, HV4, MZ5, JV3, NL4). Out of 35 fig accessions, $60 \%$ possessed green leaf colour while 40 accessions had dark green leaf colour (SD1, SD3, SD4, PN1, PN2, HV1, MZ2, MZ4, MZ5, JV1, JV2, JV3, NL3, NL4). Of the 35 fig accessions, 91.24\% of the accessions had non-lobed leaves, $5.71 \%$ of the accessions (KT7, HV2) had calcareous lobed 
leaves at the base, while 1 accession (SD2) had cordate trilobed leaves at the base. Most of the fig accessions $(71.42 \%$ ) had round leaf base, while $28.57 \%$ of fig accessions (MP3, MP4, MP5, KT7, SD2, BG1, BG2, BG7, HV2) had cordate-shaped leaf base. Regarding leaf margin, $48.57 \%$ of the $35 \mathrm{fig}$ accessions had serrated leaf margin, $40 \%$ of the fig accessions had serrated leaf margin and the remaining $11.42 \%$ of the fig accessions (SD2, SD3, PN4, HV2) had crenate leaf margin. Most of the fig accessions (91.42\%) had leaves with fully dented lobe sides, while $8.58 \%$ of the fig accessions (SD2, HV2, JV3) had dented leaves at the upper margin. In leaf veining, $88.58 \%$ of the fig accessions examined had visible leaf veining while $11.42 \%$ of the fig accessions (PN1, PN2, PN3, PN4) had slightly visible leaf veining. A wide variation was observed in the fruit shape of the collected fig germplasm. Out of the 35 fig accessions, $71.42 \%$ had globular fruit shape, 25.71\% (KT4, KT5, KT6, KT7, SD1, SD2, PN2, HV3, HV4) had an oblate shape and 2.85\% (KT2) had an oblong fruit shape. A wide variation in flesh colour was observed in all the fig accessions studied. Of the 35 fig accessions, $40 \%$ had amber flesh colour, $37.14 \%$ of the accessions were red, while $22.86 \%$ of the accessions (SD3, SD4, PN1, PN2, PN3, PN4, BG1, BG2) had pink flesh colour. All 35 fig accessions were difficult to peel.

\subsection{Descriptive Results for Quantitative Characteristics}

The descriptive statistics of minimum, maximum, means, standard deviations and coefficients of variation (CV) for 20 quantitative traits are presented in Table 3. The results showed a wide range of morphological variability in leaf and fruit traits. Several traits such as leaf width $(14.81 \%)$, petiole length $(14.77 \%)$, photosynthetic activity $(14.02 \%)$, total chlorophyll content $(13.43 \%)$ showed highest $C V$ while lowest $C V$ was recorded for fruit firmness (4.46\%). Days to maturity ranged from 71.00-86.00 for accession KT6 and NL4, respectively. Shoot length varied from $7.69-21.52 \mathrm{~cm}$ for NL4 and JV2, respectively. The number of leaves per shoot was different for KT5 and PN3 (7.65-10.30). Leaf length ranged from 7.19-12.89 cm in NL4 and MZ2. Leaf width ranged from $6.47 \mathrm{~cm}$ (MP4) to $10.12 \mathrm{~cm}$ (BH4). Leaf area varied between $38.55-90.06 \mathrm{~cm}^{2}$ for accessions MP5 and BG1. Petiole length was different for NL4 and MZ2 (17.49-38.28 mm). Petiole thickness ranged from $1.33-2.99 \mathrm{~mm}$ for BG7 and BH3. The number of fruits per shoot varied between 3.60-6.70 in SD4 and BG1. Fruit length was different in HV4 and BG1 (11.25-29.85 mm). Fruit diameter ranged from $11.85-27.49 \mathrm{~mm}$ in MP3 and NL4. The fruit stalk length ranged from 5.22-22.38 mm for accession KT6 and BG1, respectively. Fruit weight varied between 2.65 and $9.66 \mathrm{~g}$ for BH3 and BG1, respectively. The width of the ostioles was different in NL4 and BH1 (2.17-4.84 mm). The thickness of the fruit skin ranged from $0.10-0.76 \mathrm{~mm}$ at KT7 and BG2. Fruit firmness was low in SD1 and high in BH1 $\left(0.46\right.$ and $\left.0.69 \mathrm{kgcm}^{2}\right)$, respectively). The colour value $L^{*}$ ranged between $24.72-59.24$ for MP5 and BH3. The colour value $\mathrm{a}^{*}$ ranged from 1.14 to 9.51 for NL3 and $\mathrm{BH} 3$, respectively. Photosynthetic activity ranged between 7.94-10.22 $\mu \mathrm{mol} \cdot \mathrm{CO}_{2} \cdot \mathrm{m}^{-2} \mathrm{~s}^{-1}$ for BG3 and NL3. Total chlorophyll content ranged from 37.11-46.48 $\mathrm{ug} \mathrm{m}^{-1}$ for BG3 and NL3, respectively. Accessions with high fruit weight, low ostioles width and good fruit firmness with dark colour are preferred for fresh market.

\subsection{Correlation for Quantitative Characteristics}

A strong correlation was found for all of the quantitative traits studied (Table 4). The highest positive correlation was found for photosynthetic activity and total chlorophyll content (0.85). Additionally, positive correlations were examined between leaf length and leaf width (0.78), fruit length and fruit diameter (0.75), fruit weight and fruit length (0.73), and fruit weight and fruit diameter (0.72). In contrast, negative correlations were observed for quantitative traits such as the leaf petiole thickness and fruit skin thickness $(-0.25)$, leaf area and chlorophyll content $(-0.22)$, ostiole width and total chlorophyll content $(-0.20)$, leaf petiole thickness and photosynthetic activity $(-0.17)$, and ostiole width and fruit skin thickness $(-0.15)$. The study of these traits is helpful in the selection of fig germplasm for documentation. 
Table 2. Description of qualitative characteristics of 35 wild fig (Ficus palmata) accessions from Azad Jammu and Kashmir, Pakistan

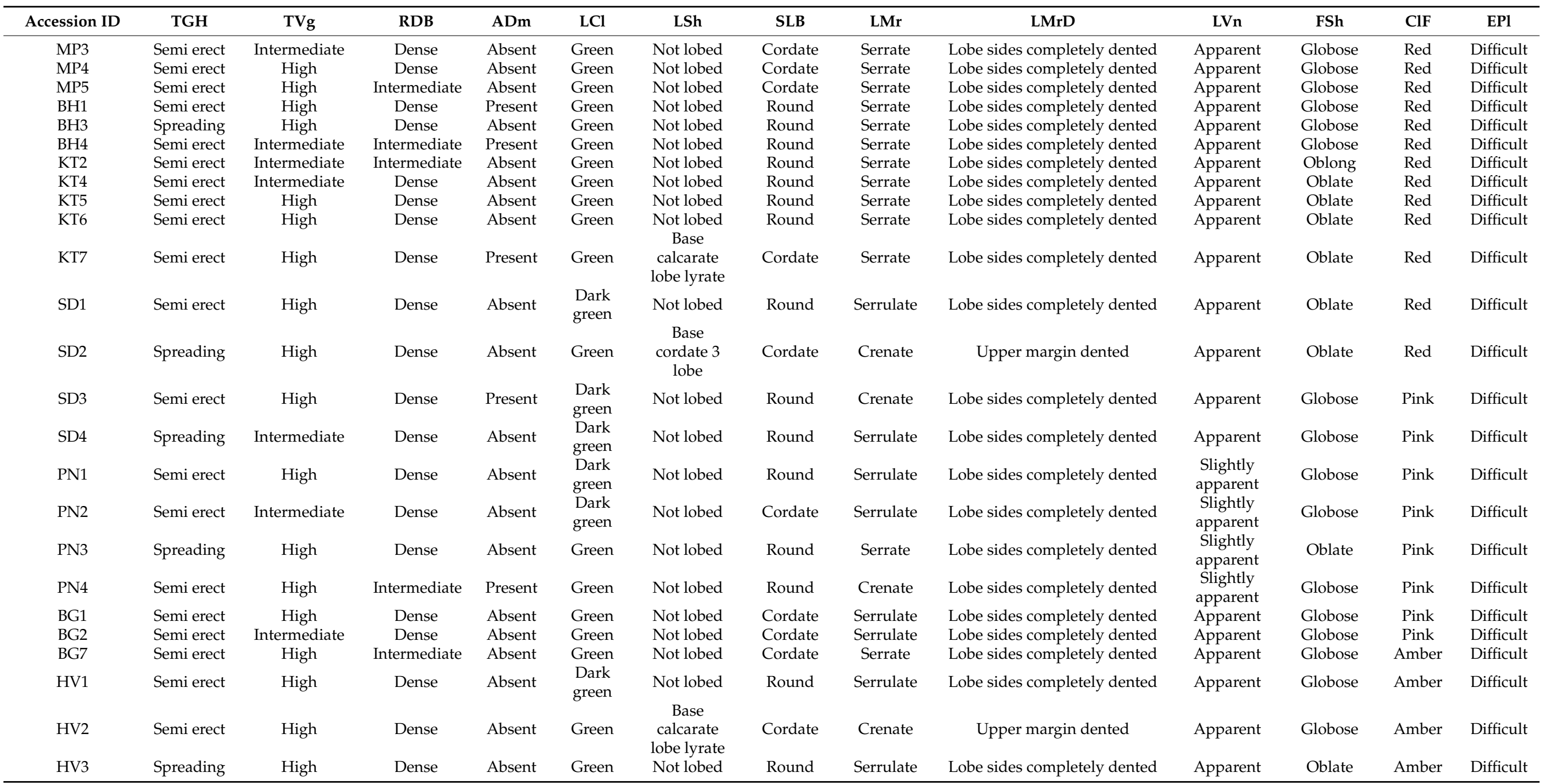


Table 2. Cont.

\begin{tabular}{|c|c|c|c|c|c|c|c|c|c|c|c|c|c|}
\hline HV4 & $\begin{array}{l}\text { Semi } \\
\text { erect }\end{array}$ & High & Intermediate & Present & Green & Not lobed & Round & Serrulate & $\begin{array}{c}\text { Lobe sides completely } \\
\text { dented }\end{array}$ & Apparent & Oblate & Amber & Difficult \\
\hline MZ2 & Spreading & Intermediate & Dense & Absent & $\begin{array}{l}\text { Dark } \\
\text { green }\end{array}$ & Not lobed & Round & Serrulate & $\begin{array}{c}\text { Lobe sides completely } \\
\text { dented }\end{array}$ & Apparent & Globose & Amber & Difficult \\
\hline MZ4 & Spreading & High & Dense & Absent & $\begin{array}{l}\text { Dark } \\
\text { green }\end{array}$ & Not lobed & Round & Serrulate & $\begin{array}{c}\text { Lobe sides completely } \\
\text { dented }\end{array}$ & Apparent & Globose & Amber & Difficult \\
\hline MZ5 & $\begin{array}{l}\text { Semi } \\
\text { erect }\end{array}$ & High & Intermediate & Present & $\begin{array}{l}\text { Dark } \\
\text { green }\end{array}$ & Not lobed & Round & Serrulate & $\begin{array}{c}\text { Lobe sides completely } \\
\text { dented }\end{array}$ & Apparent & Globose & Amber & Difficult \\
\hline JV1 & $\begin{array}{l}\text { Semi } \\
\text { erect }\end{array}$ & High & Dense & Absent & $\begin{array}{l}\text { Dark } \\
\text { green }\end{array}$ & Not lobed & Round & Serrate & $\begin{array}{c}\text { Lobe sides completely } \\
\text { dented }\end{array}$ & Apparent & Globose & Amber & Difficult \\
\hline JV2 & $\begin{array}{l}\text { Semi } \\
\text { erect }\end{array}$ & High & Dense & Absent & $\begin{array}{l}\text { Dark } \\
\text { green }\end{array}$ & Not lobed & Round & Serrulate & $\begin{array}{c}\text { Lobe sides completely } \\
\text { dented }\end{array}$ & Apparent & Globose & Amber & Difficult \\
\hline JV3 & $\begin{array}{l}\text { Semi } \\
\text { erect }\end{array}$ & High & Dense & Present & $\begin{array}{l}\text { Dark } \\
\text { green }\end{array}$ & Not lobed & Round & Serrulate & Upper margin dented & Apparent & Globose & Amber & Difficult \\
\hline NL2 & Spreading & High & Dense & Absent & Green & Not lobed & Round & Serrulate & $\begin{array}{c}\text { Lobe sides completely } \\
\text { dented }\end{array}$ & Apparent & Globose & Amber & Difficult \\
\hline NL3 & $\begin{array}{l}\text { Semi } \\
\text { erect }\end{array}$ & High & Dense & Absent & $\begin{array}{l}\text { Dark } \\
\text { green }\end{array}$ & Not lobed & Round & Serrulate & $\begin{array}{c}\text { Lobe sides completely } \\
\text { dented }\end{array}$ & Apparent & Globose & Amber & Difficult \\
\hline NL4 & $\begin{array}{l}\text { Semi } \\
\text { erect }\end{array}$ & Intermediate & Intermediate & Present & $\begin{array}{l}\text { Dark } \\
\text { green }\end{array}$ & Not lobed & Round & Serrulate & $\begin{array}{c}\text { Lobe sides completely } \\
\text { dented }\end{array}$ & Apparent & Globose & Amber & Difficult \\
\hline
\end{tabular}


Table 3. Descriptive statistics for quantitative characteristics of 35 wild fig (Ficus palmata) accessions from Azad Jammu and Kashmir, Pakistan.

\begin{tabular}{|c|c|c|c|c|c|}
\hline Characteristics & Min & $\operatorname{Max}$ & Mean & SD & CV (\%) \\
\hline Days to maturity & 71.00 & 86.00 & 67.70 & 0.57 & 11.02 \\
\hline Shoot length (cm) & 7.69 & 21.52 & 14.60 & 0.90 & 9.62 \\
\hline Number of leaf per shoot & 7.65 & 10.30 & 7.24 & 0.36 & 7.83 \\
\hline Leaf length $(\mathrm{cm})$ & 7.19 & 12.89 & 10.04 & 0.55 & 12.44 \\
\hline Leaf width $(\mathrm{cm})$ & 6.47 & 10.12 & 8.29 & 0.54 & 14.81 \\
\hline Leaf area $\left(\mathrm{cm}^{2}\right)$ & 38.55 & 90.06 & 64.31 & 5.45 & 10.63 \\
\hline Petiole length (mm) & 17.49 & 38.28 & 27.88 & 2.26 & 14.77 \\
\hline Petiole thickness (mm) & 1.33 & 2.99 & 2.16 & 0.10 & 11.34 \\
\hline Number of fruits per shoot & 3.60 & 6.70 & 5.15 & 0.27 & 7.02 \\
\hline Fruit length $(\mathrm{mm})$ & 11.25 & 29.85 & 20.55 & 1.17 & 12.60 \\
\hline Fruit diameter (mm) & 11.85 & 27.49 & 19.67 & 1.07 & 11.74 \\
\hline Fruit stalk length (mm) & 5.22 & 22.38 & 13.80 & 0.92 & 7.86 \\
\hline Fruit weight (g) & 2.65 & 9.66 & 6.15 & 0.57 & 9.57 \\
\hline Ostiole width (mm) & 2.17 & 4.84 & 3.50 & 0.22 & 7.14 \\
\hline Fruit skin thickness (mm) & 0.10 & 0.76 & 0.43 & 0.03 & 5.62 \\
\hline Fruit firmness $\left(\mathrm{kgcm}^{2}\right)$ & 0.46 & 0.69 & 0.71 & 0.04 & 4.46 \\
\hline Colour L* value & 24.72 & 59.24 & 41.98 & 3.53 & 8.70 \\
\hline Colour $\mathrm{a}^{*}$ value & 1.14 & 9.51 & 5.32 & 1.41 & 6.42 \\
\hline Photosynthetic activity $\left(\mu \mathrm{mol} \cdot \mathrm{CO}_{2} \cdot \mathrm{m}^{-2} \mathrm{~s}^{-1}\right)$ & 7.94 & 10.22 & 9.08 & 0.46 & 14.02 \\
\hline Total chlorophyll content $\left(\mu \mathrm{g} \cdot \mathrm{ml}^{-1}\right)$ & 37.11 & 46.48 & 41.80 & 0.67 & 13.43 \\
\hline
\end{tabular}

Table 4. Correlation coefficients among selected quantitative characters in 35 wild fig (Ficus palmata) accessions from Azad Jammu and Kashmir, Pakistan.

\begin{tabular}{|c|c|c|c|c|c|c|c|c|c|c|c|c|c|}
\hline & LLn & LWd & LAr & PLn & PTh & FWt & Fln & FDm & FSLn & OWd & FSTh & PAc & TCC \\
\hline LLn & 1 & & & & & & & & & & & & \\
\hline LWd & $0.78^{* *}$ & 1 & & & & & & & & & & & \\
\hline LAr & $0.67^{* *}$ & $0.70^{* *}$ & 1 & & & & & & & & & & \\
\hline PLn & $0.62^{* *}$ & $0.54^{* *}$ & $0.47^{* *}$ & 1 & & & & & & & & & \\
\hline PTh & $0.59^{* *}$ & $0.44^{* *}$ & $0.46^{* *}$ & $0.42 *$ & 1 & & & & & & & & \\
\hline FWt & $0.43^{*}$ & $0.46^{* *}$ & $0.54^{* *}$ & 0.30 & 0.12 & 1 & & & & & & & \\
\hline Fln & $0.56^{* *}$ & $0.39 *$ & 0.33 * & 0.39 & $0.39 *$ & $0.73^{* *}$ & 1 & & & & & & \\
\hline FDm & 0.45 * & $0.36^{*}$ & $0.40^{* *}$ & 0.40 * & 0.19 & $0.72^{* *}$ & $0.75^{* *}$ & 1 & & & & & \\
\hline FSLn & 0.31 & $0.25 *$ & 0.20 & 0.37 & 0.14 & 0.44 & $0.36^{*}$ & 0.31 & 1 & & & & \\
\hline OWd & 0.29 & $0.40^{*}$ & 0.36 & 0.34 & 0.42 * & 0.12 & 0.08 & 0.07 & 0.17 & 1 & & & \\
\hline FSTh & 0.11 & 0.09 & 0.13 & 0.02 & -0.25 & $0.58^{* *}$ & 0.45 & $0.50 * *$ & $0.55^{* *}$ & -0.15 & 1 & & \\
\hline PAc & 0.03 & 0.25 & -0.07 & 0.08 & -0.17 & 0.50 & 0.31 & 0.26 & 0.18 & -0.14 & 0.34 & 1 & \\
\hline TCC & -0.03 & 0.09 & -0.22 & -0.03 & -0.14 & 0.34 & 0.23 & 0.14 & 0.13 & -0.20 & 0.22 & $0.85^{* *}$ & 1 \\
\hline
\end{tabular}

** is highly significant at $p \leq 0.01$; ${ }^{*}$ is significant at $p \leq 0.05$. Abbreviations: Leaf length (LLn), Leaf width (LWd), Leaf area (LAr), Petiole length (PLn), Petiole thickness (PTh), Fruit weight (FWt), Fruit length (Fln), Fruit diameter (FDm), Fruit stalk length (FSLn), Ostiole width (OWd), Fruit skin thickness (FSTh), Photosynthetic activity (PAc) and Total chlorophyll content (TCC).

\subsection{Principal Component Analysis (PCA) for Quantitative Characteristics}

A PCA plot was created based on the first two components. In the individual plots, all 35 fig accessions were distributed in four quadrants, showing great diversity (Figure 2). For example, five accessions (BG1, NL4, NL3, NL2, BG2) with the highest leaf length, leaf width, leaf area, leaf petiole length, leaf petiole thickness, fruit length, fruit diameter, fruit weight, ostiole width and fruit firmness were located away from the axis centre on the upper plane. Similarly, fig accessions BH4, BH3 and BH1 had the smallest leaf length, leaf width, leaf area, leaf petiole length, leaf petiole thickness, fruit length, fruit diameter, fruit weight, ostiole width and fruit firmness, and were located at the lower level away from the axis centre. 


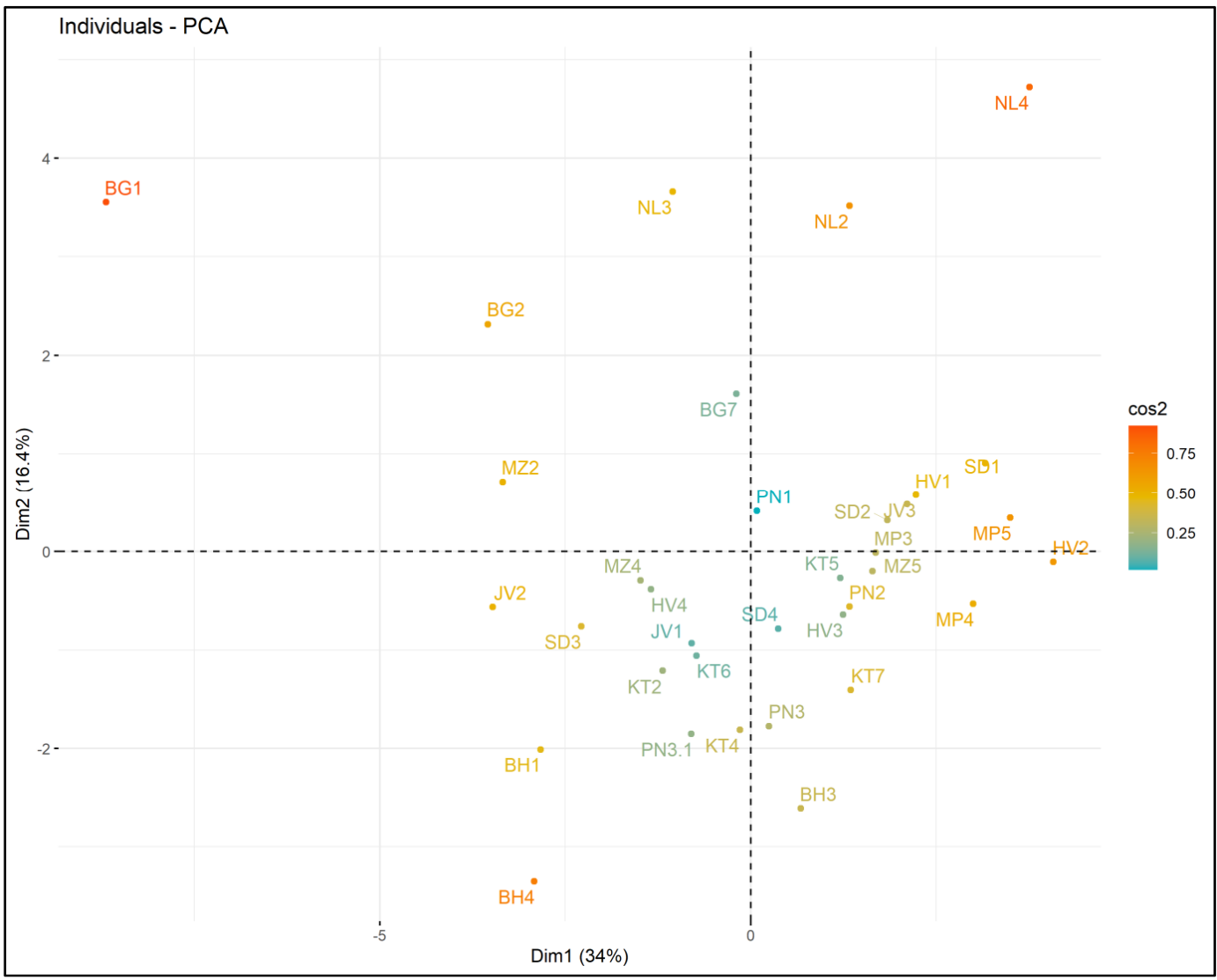

Figure 2. Distribution of 35 wild fig (Ficus palmata) accessions in quadrants showing phenotypic variation.

\section{Discussion}

\subsection{Qualitative and Quantitative Characterization}

In the present study, the quantitative and qualitative differences among 35 wild fig accessions from Azad Jammu and Kashmir, Pakistan were described to identify unique ecotypes. This study will not only help to understand more about these fig accessions but also help to improve their conservation, management for breeding and organisation of their orchards to achieve high yields. In a recent study by Hssaini et al. [26], it was found that such characterization studies have also proved useful for genetic identification in other fruit crops. Traits related to tree growth habit, leaf length, leaf width, fruit shape, fruit colour, flesh colour, photosynthetic activity and total chlorophyll content were reported to be very important for economic studies. Moreover, these traits can be used by fig breeders and fig farmers. The diversity assessment studies are always a good support for the survival of a population in the face of many natural disturbances and climatic problems [27]. The results of this study will be helpful to understand the morpho-pomological contents of the fruits which could be used to distinguish between cultivars as well as to estimate the genetic affiliation of different fig accessions. Similar studies conducted previously also mentioned the importance of both quantitative and qualitative traits for identification and evaluation of fig germplasm $[4,5,26,28]$. Based on significant differences between quantitative and qualitative characteristics, many conclusions have been drawn and fruit germplasm has been classified into different groups. In this context, many researchers around the world \{Turkey [12,29], Iran [4,30], Malaysia [31], Morocco [2,8], Tunisia [32,33], Spain [34,35], Jordan [36], Algeria [37]\} and Kashmir [23,28] have also worked on fig germplasm and reported variabilities in morphological and pomological characteristics. The current results are sufficiently informative and could be used to exploit diversification among the accessions studied. In addition, these results could also lead to the exploration of new potential areas of interest such as breeding and genetics research, domestication 
and the commercialization of selected wild fig accessions. In addition, based on the results of this study, various targeted breeding programmes could be initiated to improve fruit quality and fruit size. It is known that fig plants have a wider distribution range, so it is very likely that new ecotypes could be developed [26]. The results also showed that fruit size and flesh colour were highly variable among wild fig accessions. These variations among fig accessions grown in the same geographical regions could be due to differences in genetic makeup or environmental conditions [38,39]. Similar results were reported by Sezen et al. [40], who found that there was a great diversity among fig accessions in terms of fruit size and yield and also for flesh colour. They also found that these traits are usually controlled by the action of additive genes and could be useful for cultivar selection. It is a fact that accessions with larger fruits are suitable for fresh consumption, while accessions with smaller fruits are suitable for processing. Variations in fruit size of figs have also been reported by Simsek et al. [41] and Caliskan et al. [42].

Variations in fruit length and width have also been noted and are considered important traits for breeding programmes. Fruit dimension studies are crucial for the evaluation of packing and shipping $[40,41]$. Significant variations were observed in leaf length and width among the accessions studied. Leaves are the most important plant parts as they help to absorb sunlight for photosynthesis. Thus, as the leaf size increases, the leaf area also increases, which contributes to an effective supply of primary metabolites for the production of secondary metabolites [43]. Skin colour, flesh colour and fruit firmness are also important traits for commercial purposes. However, among these traits, fruit firmness is most commonly used in research as it helps to assess fruit maturity and quality. Most growers also use fruit firmness as one of the criteria for assessing fruit maturity and quality, as it is directly related to fruit storability. Fruit firmness was determined for the first time in selected fig accessions, and it was found that the values were low in all fig accessions. Skin colour is also an important ripening criterion and commercially used parameter that could be helpful in the classification and selection of cultivars [40].

A wide phenotypic diversity was also observed in qualitative traits. In the selection of fig cultivars for commercial cultivation, traits such as tree growth habit and type of fruiting are considered very important. Semi-erect growth habit was observed in wild germplasm as it is mostly found in temperate climates with abundant rainfall. Caliskan and Polat [29] and Mir et al. [23] also reported the semi-erect growth habit and fruiting on current year shoot. The most important traits affecting the commercial value of the crop for fresh consumption are fruit shape, fruit weight, length and width $[26,28,30]$. These traits are polygenic in nature. Fruit shape has been described as oblate, oblong and globose. Most of the wild germplasm studied was accounted with globose fruit shape. Such variations in fruit shape, fruit size and flesh colour were also reported by Mir et al. [23] in central Kashmir and Khadivi et al. [4] in Iran. Fruit ribs varied in morphology from intermediate to none, in addition to prominent ribs [44]. Significant genotypic differences were found by Simsek et al. [41] and Fatahi et al. [30] in the absence of fruit pedicel and ease of peeling. These types of variations may be due to differences in genetic makeup and ecological conditions [40]. All fig accessions studied were sweeter in taste, which can be recommended for fresh fruit consumption. In this study, a wide variation in morphological parameters such as shape, colour and size of fruits was detected. In Azad Jammu and Kashmir, Pakistan, fig growers have given names to different accessions based on their fruit characteristics and their growing locations. Based on these characteristics, local farmers have named fig accessions as Pagwhara (flattened shape, smaller size, dark purple colour).

\subsection{Quantitative Correlations}

Using a simple correlation coefficient analysis, significant correlations were found between the quantitative characteristics. The strongest positive correlation was found for photosynthetic activity and total chlorophyll content. In addition, positive correlations were examined between leaf length and leaf width, fruit length and fruit diameter, fruit weight and fruit length, and fruit weight and fruit diameter. These results are in agreement 
with those of Khadivi-Khub and Anjam [43] and Khadivi et al. [4]. The presence of strong positive correlations between leaf characteristics and photosynthetic activity and total chlorophyll content indicates that larger leaf area leads to higher photosynthetic activity [45]. Negative correlations were also found for quantitative traits such as leaf petiole thickness and fruit skin thickness, leaf area and chlorophyll content, ostiole width and total chlorophyll content, leaf petiole thickness and photosynthetic activity, and ostiole width and fruit skin thickness. The study of these traits is helpful in the selection of fig germplasm for documentation. The presence of negative correlations between leaf area and total chlorophyll content suggests that a greater leaf area should result in lower total chlorophyll content at the fruit maturity stage.

Similar PCA studies have been previously conducted to evaluate the differences among fruit tree species such as apricot [46], cherry [47,48], ber [49] and jaman [50]. Diversity depends on the variations present in the populations under study. Heterosis is generally measured by the degree of genetic diversity between parental combinations. Therefore, traits with high correlations could be useful for future analysis of fig accessions.

\subsection{Perspectives of Gene Bank Conservation}

Figs are highly nutritious fruits and given the circumstances of malnutrition in the world, they are considered a boon as they can combat the problem of malnutrition to some extent [38]. However, fig borers, mealy bugs and scale insects are important pests while fig mosaic disease and fig rust are important diseases reported to cause heavy losses in fig orchards [51-53]. Modern techniques of selection and breeding of improved cultivars have greatly reduced the diversity of many fruit crops $[49,50,54]$. This narrowing of plant diversity has resulted in the disappearance of many plant species and has had a negative impact on biodiversity [55]. The accessions collected in this study had a great diversity in quantitative and qualitative traits and a high degree of variation among traits, indicating that these accessions have great strength and potential for further exploitation. Many countries have similar germplasm collections for other minor fruits such as ber, pomegranate, litchi, jaman, etc., consisting of most of the possible varieties of these fruits in these countries. Similarly, fig collections have been reported from different countries such as Tunisia [32,33], Turkey [12,29,56], Morocco [8,57,58], Spain [35,59], Lebanon [60], Iran [4], Kashmir [23,38] and Jordan [36]. These studies have shown that the diversity of morphological and pomological characters could be useful for an efficient marker system to distinguish between different fig genotypes.

The current results support the idea that morphological and pomological traits are reliable parameters to estimate the genetic relationships among fig accessions and can be effectively used to discriminate among different fig accessions. Similarly, many studies $[4,26,61,62]$ have shown that morphological and pomological characters are very helpful in identifying and evaluating fig germplasm. In Azad Jammu and Kashmir, Pakistan, fig is widely distributed in wild and cultivated form and shows very high diversity among different accessions. However, very little attention has been paid to the characterization and conservation of local fig germplasm. This is the first comprehensive study of its kind on the characterization and conservation of 35 wild fig accessions. Thus, the germplasm conserved in this study could be used as source material for future biotic and abiotic studies and also for breeding programs [49].

\subsection{Perspectives of Breeding}

The basic objective of breeding is to combine the most desired traits in a single variety [63]. In order to exploit the potential of a native crop in a particular area, extensive characterization studies must be conducted [64]. These studies, along with breeding programmes, can result in varieties with better yields, good quality and higher nutritional value of fruits. Pakistan is blessed with rich resources and considerable variability for figs. A little research on characterization, breeding and commercialization can lead to the development of valuable products and in return, rural people can earn a better living. 
In our research, correlations were found between the traits studied, which could play an important role in improving fruit yield and quality. Large fruits of wild fig accessions (BG1, NL3, MZ2, BG2) can be crossed to produce high yielding and high quality cultivars. Flesh colour is an important criterion for consumer acceptance, and in our study it ranged from red to pink to amber. Therefore, fig accessions (MP3, MP4, MP5, BH1, BH3, BH4, $\mathrm{KT} 2, \mathrm{KT} 4, \mathrm{KT} 5, \mathrm{KT} 6, \mathrm{KT} 7, \mathrm{SD} 1, \mathrm{SD} 2)$ with a red flesh colour can be used to produce fruit varieties with red flesh colour. Such types of accessions are good for fresh consumption and can contribute to the improvement of fresh fruit market. Similarly, several promising accessions such as ML-G-17, AH-S-06 and DH-S-04 have been identified by researchers in central Kashmir in the north-western Himalayan region [23] based on flesh colour, external fruit colour and fruit shape.

Diversity between accessions located in the same cluster is minimal and few segregates are possible through hybridization [65]. Therefore, accessions belonging to different clusters should be crossed, as they will produce hybrids with higher heterosis and genetic recombination. Environment can also play an important role in breeding different accessions [66]. So, in order to achieve the best breeding results, the environmental effects must be minimised. In the present study, accessions that have great diversity and are well adapted to the local environment were selected. Thus, in hybridization, the environmental influences could be minimised by selecting those accessions which are considered to be very stable in terms of trait expression [67]. The extent of genetic variation can also be determined using genetic markers for genetic analysis [54]. To utilise the diversity of collected fig germplasm from Azad Jammu and Kashmir, Pakistan, it is proposed to use genetic markers for further confirmation.

\section{Conclusions}

Significant differences in quantitative and qualitative traits were found in 35 wild fig accessions. The results show that each accession has its own individual characteristics and identity. Studies related to characterization could be useful to identify diversity and highlight the most appropriate variables. Moreover, these studies are of great help in the development of new varieties, either through genetics or breeding programmes. The results of the present study could also be useful in future for conservation of germplasm resources, biochemical studies and other studies for the development of cultivars with large fruits, seedless fruits, fruits with red flesh colour and sweeter taste. The limitation of this study is that it only considers qualitative and quantitative characteristics of plants without genetic studies and collecting chemical data on fruit quality. However, for accurate description of fig germplasm from Azad Jammu and Kashmir, Pakistan, future studies should be carried out for molecular evaluation and biochemical characterization. The traits studied are of importance to further the existing knowledge about native wild figs, which can improve the sustainability of local communities.

Author Contributions: Conceptualization, M.R.K. and M.A.K.; data curation, M.R.K., U.H. and R.M.R.; formal analysis, M.R.K., S.I.A. and M.M.; methodology, M.R.K., M.A.K. and R.M.R.; project administration, M.R.K. and U.H.; visualization, M.M. and M.A.K.; Writing-Original draft, M.R.K., M.M., U.H. and B.D.; writing-review and editing, M.R.K., S.I.A., M.M. and B.D. All authors have read and agreed to the published version of the manuscript.

Funding: This research received no external funding.

Institutional Review Board Statement: Not applicable.

Informed Consent Statement: Not applicable.

Data Availability Statement: Not applicable.

Acknowledgments: This study is part of PhD research. The authors are highly thankful to Nadeem Akhtar Abbasi (Late) who died during this research period due to COVID-19. The idea to exploit fig germplasm from Azad Jammu and Kashmir region was his brainchild. Further, the University of 
Poonch Rawalakot, Azad Jammu and Kashmir is highly acknowledged for granting study leave to the main author.

Conflicts of Interest: The authors declare no conflict of interest.

\section{References}

1. Khadari, B.; Grout, C.; Santoni, S.; Kjellberg, F. Contrasted genetic diversity and differentiation among Mediterranean populations of Ficus carica L.: A study using mtDNA RFLP. Genet. Resour. Crop Evol. 2005, 52, 97-109. [CrossRef]

2. Hmimsa, Y.; Aumeeruddy-Thomas, Y.; Ater, M. Vernacular taxonomy, classification and varietal diversity of fig (Ficus carica L.) among Jbala cultivators in northern Morocco. Human Ecol. 2012, 40, 301-313. [CrossRef]

3. Hirst, K. Fig trees and archaeology. The history of the domestication of fig trees. About. Com Archaeol. 1996. Available online: http:/ / archaeology.about.com/od/domestications/a/fig_trees.htm (accessed on 26 July 2018).

4. Khadivi, A.; Anjam, R.; Anjam, K. Morphological and pomological characterization of edible fig (Ficus carica L.) to select the superior trees. Sci. Hortic. 2018, 238, 66-74. [CrossRef]

5. Kislev, M.E.; Hartmann, A.; Bar-Yosef, O. Early domesticated fig in the Jordan Valley. Science 2006, 312, 1372-1374. [CrossRef] [PubMed]

6. Duenas, M.; Perez-Alonso, J.J.; Santos-Buelga, C.; Escribano-Bailon, T. Anthocyanin composition in fig (Ficus carica L.). J. Food Compo. Anal. 2008, 21, 107-115. [CrossRef]

7. Flaishman, M.A.; Rodov, V.; Stover, E. The fig: Botany, horticulture and breeding. Hortic. Rev. 2008, 34, $113-197$.

8. Hssaini, L.; Charafi, J.; Hanine, H.; Ennahli, S.; Mekaoui, A.; Mamouni, A.; Razouk, R. Comparative analysis and physiobiochemical screening of an ex-situ fig (Ficus carica L.) collection. Hortic. Environ. Biotechnol. 2019, 60, 671-683. [CrossRef]

9. Slatnar, A.; Klancar, U.; Stampar, F.; Veberic, R. Effect of drying of figs (Ficus carica L.) on the contents of sugars, organic acids and phenolic compounds. J. Agric. Food Chem. 2011, 59, 11696-11702. [CrossRef]

10. Tomas-Barberan, F.A.; Espin, J.C. Phenolic compounds and related enzymes as determinants of quality in fruits and vegetables. J. Sci. Food Agric. 2001, 81, 853-876. [CrossRef]

11. Veberic, R.; Colaric, M.; Stampar, F. Phenolic acids and flavonoids of fig fruit (Ficus carica L.) in the northern Mediterranean region. Food Chem. 2008, 106, 153-157. [CrossRef]

12. Ercisli, S.; Tosun, M.; Karlidag, H.; Dzubur, A.; Hadziabulic, S.; Aliman, Y. Color and antioxidant characteristics of some fresh fig (Ficus carica L.) genotypes from Northeastern Turkey. Plant Foods Human Nutr. 2012, 67, 271-276. [CrossRef] [PubMed]

13. Duke, J.A. Handbook of Medicinal Herbs; CRC Press: Boca Raton, FL, USA, 2002.

14. Pimbert, M. Sustaining the Multiple Functions of Agricultural Biodiversity. FAO Background Paper Series for the Conference on the Multifunctional Character of Agriculture and Land, The Netherlands, September 1999. Available online: https:/ / pubs.iied. org/sites/default/files/pdfs/migrate/G01250.pdf (accessed on 20 August 2019).

15. Esquinas-Alcázar, J. Protecting crop genetic diversity for food security: Political, ethical and technical challenges. Nat. Rev. Genet. 2005, 6, 946-953. [CrossRef]

16. Abbasi, A.M.; Shah, M.H.; Khan, M.A. Wild Edible Vegetables of Lesser Himalayas: Ethnobotanical and Nutraceutical Aspects; Springer International Publishing: Cham, Switzerland, 2014; Volume 1, p. 360.

17. Ajaib, M.; Khan, Z. Ethnobotanical Studies of Useful Trees of District Kotli, Azad Jammu and Kashmir. Biologia 2014, 60, 63-71.

18. Bisht, J.K.; Srivastva, A.K.; Gupta, H.S. Sustainable fodder production management in NW Himalaya. Tech. Bulletin. Almora VPKAS 2009, 32, 1-62.

19. Sbhatu, D.B.; Tekle, H.T.; Tesfamariam, K.H. Ficus palmata Forskål (BELES ADGI) as a source of milk clotting agent: A preliminary research. BMC Res. Notes 2020, 13, 446. [CrossRef]

20. Tewari, D.; Gupta, P.; Bawari, S.; Sah, A.N.; Barreca, D.; Khayatkashani, M.; Khayat Kashani, H.R. Himalayan Ficus palmata L. Fruit extract showed in vivo central and peripheral analgesic activity involving COX-2 and Mu opioid receptors. Plants 2021, 10, 1685. [CrossRef]

21. Mahmood, A.; Qureshi, R.; Mahmood, A.; Sangi, Y.; Shaheen, H.; Ahmad, I.; Nawaz, Z. Ethnobotanical survey of common medicinal plants used by people of district Mirpur, AJK, Pakistan. J. Med. Plants Res. 2011, 5, 4493-4498.

22. Qureshi, R.A.; Ghufran, M.A.; Gilani, S.A.; Sultana, K.; Ashraf, M. Ethnobotanical studies of selected medicinal plants of Sudhan Gali and Ganga Chotti hills, district Bagh, Azad Kashmir. Pak. J. Bot. 2007, 39, 2275-2283.

23. Mir, M.M.; Amit, K.; Umar, I.; Mir, S.A.; Rehman, M.U.; Banday, S.A.; Rather, G.H.; Sibat, F. Characterization of fig (Ficus carica L.) germplasm in central Kashmir of North Western Himalayan region. Indian J. Plant Genet. Resour. 2018, 31, 57-63. [CrossRef]

24. Arnon, D.I. Copper enzymes in isolated chloroplasts. Polyphenoloxidase in Beta vulgaris. Plant Physiol. 1949, 24, 1-12. [CrossRef] [PubMed]

25. IPGRI and CIHEAM. Descriptors for Figs. International Plant Genetic Resources Institute (IPGRI), Rome, Italy, and the International Centre for Advanced Mediterranean Agronomic Studies (CIHEAM), Paris, France, 2003. Available online: https:/ / www.bioversityinternational.org/fileadmin/user_upload/online_library/publications/pdfs/907.pdf (accessed on 18 December 2019). 
26. Hssaini, L.; Hanine, H.; Razouk, R.; Ennahli, S.; Mekaoui, A.; Ejjilani, A.; Charafi, J. Assessment of genetic diversity in Moroccan fig (Ficus carica L.) collection by combining morphological and physicochemical descriptors. Genet. Resour. Crop Evol. 2020, 67, 457-474. [CrossRef]

27. Awasthi, O.P.; More, T.A. Genetic diversity and status of Zizyphus in India. Acta Hortic. 2009, 10, 33-40. [CrossRef]

28. Podgornik, M.; Vuk, I.; Vrhovnik, I.; Mavsar, D.B. A survey and morphological evaluation of fig (Ficus carica L.) genetic resources from Slovenia. Sci. Hortic. 2010, 125, 380-389. [CrossRef]

29. Caliskan, O.; Polat, A.A. Morphological diversity among fig (Ficus carica L.) accessions sampled from the Eastern Mediterranean region of Turkey. Turkish J. Agric. For. 2012, 36, 179-193.

30. Fatahi, S.; Cheghamirza, K.; Arji, I.; Zarei, L. Evaluation of genetic variation of common fig (Ficus carica L.) in West of Iran. J. Med. Plants By-Prod. 2017, 6, 229-240.

31. Isa, M.M.; Jaafar, M.N.; Kasim, K.F.; Mutalib, M.F.A. Cultivation of fig (Ficus carica L.) as an alternative high value crop in Malaysia: A brief review. IOP Conf. Ser. Mater. Sci. Eng. 2020, 864, 012134. [CrossRef]

32. Saddoud, O.; Baraket, G.; Chatti, K.; Trifi, M.; Marrakchi, M.; Mars, M.; Salhi-Hannachi, A. Using morphological characters and simple sequence repeat (SSR) markers to characterize Tunisian fig (Ficus carica L.) cultivars. Acta Biol. Cracoviensia. Ser. Bot. Wars. 2011, 53, 7. [CrossRef]

33. Aljane, F.; Nahdi, S.; Essid, A. Genetic diversity of some accessions of Tunisian fig tree (Ficus carica L.) based in morphological and chemical traits. J. Nat. Prod. Plant Resour. 2012, 2, 350-359.

34. Pérez-Sánchez, R.; Morales-Corts, M.R.; Gómez-Sánchez, M.A. Agro-morphological diversity of traditional fig cultivars grown in Central-Western Spain. Genetika 2016, 48, 533-546. [CrossRef]

35. Pereira, C.; Corrales, M.L.; Villalobos, M.C.; Córdoba, M.G.; Serradilla, M.J. Physicochemical and nutritional characterization of brebas for fresh consumption from nine fig varieties (Ficus carica L.) grown in Extremadura (Spain). J. Food Qual. 2017, 12, 6302109.

36. Ateyyeh, A.F.; Sadder, M.T. Growth pattern and fruit characteristics of six common fig (Ficus carica L.) cultivars in Jordan. Jordan J. Agric. Sci. 2006, 2, 105-112.

37. Benettayeb, Z.; Bencheikh, M.; Setti, B.; Chaillou, S. Genetic diversity of Algerian fig (Ficus carica L.) cultivars based on morphological and quality traits. Indian J. Hortic. 2017, 74, 311-316. [CrossRef]

38. Naseer, M.A.; Maqbool, M.; Rafiq, S.; Zahid, N.; Hamid, A.; Shah, S.Z.A. Comparative analysis of physical and biochemical attributes of edible fi (Ficus carica L.) collected from three districts of Azad Jammu and Kashmir located at diffrent elevations. Pak. J. Agric. Res. 2020, 33, 707-713.

39. Saddoud, O.; Baraket, G.; Chatti, K.; Trifi, M.; Marrakchi, M.; Salhi-Hannachi, A.; Mars, M. Morphological variability of fig (Ficus carica L.) cultivars. Int. J. Fruit Sci. 2008, 8, 35-51. [CrossRef]

40. Sezen, I.; Ercisli, S.; Gozlekci, S. Biodiversity of figs (Ficus carica L.) in Coruh valley of Turkey. Erwerbs Obstbau 2014, 56, 139-146. [CrossRef]

41. Simsek, M.; Gulsoy, E.; Kirar, M.Z.; Yucel, Y. Identification and selection of some female fig (Ficus carica L.) genotypes from Mardin province of Turkey. Pak. J. Bot. 2017, 49, 541-546.

42. Caliskan, O.; Bayazit, S.; Iigin, M.; Karatas, N. Morphological diversity of caprifig (Ficus carica var. caprificus) accessions in the eastern Mediterranean region of Turkey: Potential utility for caprification. Sci. Hortic. 2017, 222, 46-56. [CrossRef]

43. Khadivi-Khub, A.; Anjam, K. Morphological characterization of Prunus scoparia using multivariate analysis. Plant Syst. Evol. 2014, 300, 1361-1372. [CrossRef]

44. Polat, A.A.; Caliskan, O. Fruit characteristics of table fig (Ficus carica) cultivars in subtropical climate conditions of the Mediterranean region. N. Zeal. J. Crop. Hortic. Sci. 2008, 36, 107-115. [CrossRef]

45. Zulkarnaini, Z.M.; Sakimin, S.Z.; Mohamed, M.T.M.; Jaafar, H.Z. Changes in leaf area index, leaf mass ratio, net assimilation rate, relative growth rate and specific leaf area two cultivars of fig (Ficus Carica L.) treated under different concentrations of brassinolide. AGRIVITA J. Agric. Sci. 2019, 41, 158-165. [CrossRef]

46. Ruiz, D.; Egea, J. Phenotypic diversity and relationships of fruit quality traits in apricot (Prunus armeniaca L.) germplasm. Euphytica 2008, 163, 143-158. [CrossRef]

47. Khadivi-Khub, A.; Jafari, H.R.; Zamani, Z. Phenotypic and genotypic variation in Iranian sour and duke cherries. Trees 2013, 27, 1455-1466. [CrossRef]

48. Rakonjac, V.; Mratinić, E.; Jovković, R.; Fotirić Akšić, M. Analysis of morphological variability in wild cherry (Prunus avium L.) genetic resources from Central Serbia. J. Agric. Sci. Technol. 2014, 16, 151-162.

49. Sharif, N.; Jaskani, M.J.; Naqvi, S.A.; Awan, F.S. Exploitation of diversity in domesticated and wild ber (Ziziphus mauritiana Lam.) germplasm for conservation and breeding in Pakistan. Sci. Hortic. 2019, 249, 228-239. [CrossRef]

50. Din, S.; Jaskani, M.J.; Naqvi, S.A.; Awan, F.S. Diversity and divergence in domesticated and wild jamun (Syzygium cumini) genotypes of Pakistan. Sci. Hortic. 2020, 273, 109617. [CrossRef]

51. Himelrick, D.G. Fig production guide. Alabama Cooperative Extension System, ANR-1145, 1999. Available online: https://www. aces.edu/wp-content/uploads/2020/01/ANR-1145_FigProductionGuide_010620-L-G-copy.pdf (accessed on 19 February 2018)

52. Jahén-Rivera, S.N.; Gómez-Rodríguez, O.; Espinosa-Victoria, D. Isolation and identification of pathogens causing stem rot of the fig tree (Ficus carica). Rev. Mex. Fitopatol. 2020, 38, 269-279. [CrossRef] 
53. Preising, S.; Borges, D.F.; Ambrósio, M.M.Q.; da Silva, W.L. A fig deal: A global look at fig mosaic disease and its putative associates. Plant Dis. 2021, 105, 727-738. [CrossRef] [PubMed]

54. Mehmood, A.; Jaskani, M.J.; Khan, I.A.; Ahmad, S.; Ahmad, R.; Luo, S.; Ahmad, N.M. Genetic diversity of Pakistani guava (Psidium guajava L.) germplasm and its implications for conservation and breeding. Sci. Hortic. 2014, 172, 221-232. [CrossRef]

55. Mastretta-Yanes, A.; Gasman, F.A.; Burgeff, C.; Ramírez, M.C.; Piñero, D.; Sarukhán, J. An intitiative for the study and use of genetic diversity of domesticated plants and their wild relatives. Front. Plant Sci. 2018, 9, 209. [CrossRef] [PubMed]

56. Caliskan, O.; Bayazit, S.; Kilic, D.; Ilgin, M.; Karatas, N. Pollen morphology and variability of caprifig (Ficus carica var. caprificus) genetic resources in Turkey using multivariate analysis. Sci. Hortic. 2021, 287, 110283. [CrossRef]

57. Alter, M.; El Oualkadi, A.; Achtak, H.; Oukabli, A.; Khadari, B. Diversity of the local varieties of the fig tree in the North-Western Morocco. Acta Hortic. 2008, 79, 69-76. [CrossRef]

58. Achtak, H.; Ater, M.; Oukabli, A.; Santoni, S.; Kjellberg, F.; Khadari, B. Traditional agroecosystems as conservatories and incubators of cultivated plant varietal diversity: The case of fig (Ficus carica L.) in Morocco. BMC Plant Biol. 2010, 10, 28 [CrossRef]

59. Sanchez, M.J.; Melgarejo, P.; Hernandez, F.; Martinez, J.J. Chemical and morphological characterization of four fig tree cultivars (Ficus carica L.) grown under similar culture conditions. Acta Hortic. 2002, 605, 33-36. [CrossRef]

60. Chalack, L.; Chehade, A.; Mattar, E.; Khadari, B. Morphological characterization of fig accessions cultivated in Lebanon. Acta Hortic. 2008, 798, 54-61. [CrossRef]

61. Condit, I. Fig varieties: A monograph. Hilgardia 1955, 23, 323-538. [CrossRef]

62. Oukabli, A.; Mamouni, A.; Laghezali, R.; Khadari, B.; Roger, J.P.; Kjellberg, F.; Ater, M. Genetic variability in Morrocan fig cultivars (Ficus carica) based on morpholigical and pomological data. Acta Hortic. 2002, 605, 54-60.

63. Samadia, D.K.; Haldhar, S.M. Breeding strategies and scope of improvement in arid zone fruit crop-plants under abiotic stressed agro-climate: An analysis. J. Agric. Ecol. 2017, 4, 1-13. [CrossRef]

64. Samadia, D.K.; Pareek, O.P. Fruit quality improvement in pomegranate under hot arid environment. Indian J. Hortic. 2006, 63, 126-132.

65. Roy, A.; de Melo, J.; Chaurvedi, D.; Thein, T.; Cabrera-Socorro, A.; Houart, C.; Meyer, G.; Blackshaw, S.; Tole, S. LHX2 is necessary for the maintenance of optic idedentity and for the progression of optic morphogenesis. J. Neurosci. 2013, 33, 6877-6884. [CrossRef]

66. Perfectti, F.; Camacho, J.P.M. Analysis of genotypic differences in developmental stability in Annona cherimola. Evolution 1999, 53, 1396-1405. [CrossRef] [PubMed]

67. Pommer, C.V.; Murakami, K.R.N. Breeding guava (Psidium guajava L.). In Breeding Plantation Tree Crops: Tropical Species; Jain, S.M., Priyadarshan, P.M., Eds.; Springer Science + Buseniess Media, LLC.: Berlin/Heidelberg, Germany, 2009; pp. 83-120. 